\title{
A magyar morfológia elsajátításának kezdetei
}

Gervain Judit

CNRS, Párizs

\begin{abstract}
Összefoglaló
Pszicholingvisztikai szempontból igen jelentős, és máig vitatott kérdés, hogyan dolgozzák fel a beszélők a morfológiailag komplex szóalakokat: egészlegesen, elemeikre bontva vagy a két stratégiát flexibilisen használva. Még kevésbé ismert, hogyan sajátítható el a magyar és a hozzá hasonló nyelvek komplex agglutináló morfológiája. A magyar morfológia elsajátítását óvodás korú és annál nagyobb gyermekek beszédében az elmúlt évtizedekben nagy részletességgel feltárták. Sokkal kevesebbet tudunk azonban e tanulási folyamat kezdeteiről. A jelen tanulmány néhány újabb kutatást foglal össze, amelyek magyar csecsemők beszédészlelésében és nyelvfeldolgozásában vizsgálják az alaktan kibontakozásának kezdeteit, különösképpen a magánhangzó-harmónia és a morfológiai dekompozíció megjelenését.
\end{abstract}

Kulcsszavak: magyar morfológia, nyelvelsajátítás, beszédpercepció, csecsemők, magánhangzó-harmónia, alaktani dekompozíció

\section{Bevezetés}

A magyar szóalakok közismerten hosszúak és bonyolultak lehetnek. Ki ne hallott volna olyan példákat, mint „megszentségteleníthetetlenségeskedéseitekért”? Pszicholingvisztikai szempontból igen jelentős, és máig vitatott kérdés, hogyan képesek az anyanyelvi beszélők e formákat a beszédértés során feldolgozni (GergelyPléh 1994; Pléh-Lukács 2001; Milin-Smolka-Feldman 2017). Még rejtélyesebb, hogyan sajátítható el a magyar és a hozzá hasonló nyelvek komplex agglutináló morfológiája (Slobin-Bever 1982; Goldowsky-Newport 1993; Pinker 1997; Lukács-Racsmány-Pléh 2001; Pléh-Lukács-Racsmány 2003).

A magyar morfológia elsajátítását óvodás korú és annál nagyobb gyermekek beszédében Brian MacWhinney (MacWhinney 1975; MacWhinney-Pléh-Bates 1985), Pléh Csaba és munkatársaik az elmúlt évtizedekben nagy részletességgel feltárták (Pléh 1980; Pléh-Lukács 2001; Pléh-Palotás-Lőrik 2002; Pléh-LukácsRacsmány 2003). A jelen tanulmány néhány újabb kutatást foglal össze (GonzalezGomez et al. 2019; Ladányi-Kovács-Gervain elbírálás alatt), amelyek a csecsemők beszédpercepciójában vizsgálják az alaktan kibontakozásának kezdeteit, különösképpen a magánhangzó-harmónia és a morfológiai dekompozíció megjelenését.

\subsection{A morfológiai reprezentációk elméletei felnőtteknél}

A felnőtt beszélők képesek korábban soha nem hallott toldalékolt szóalakokat létrehozni és megérteni. Hogy ezt pontosan milyen mechanizmusok teszik lehetővé, az részben még ma, több mint 4 évtizednyi kutatás után is vitatott (Sandra-Taft 1994; 
Giraudo-Dal Maso 2016; Leminen et al. 2016). A vita részleteit itt nincs mód bemutatni, csak a legfontosabb elméleti álláspontokra térünk ki.

Az egészleges elméletek szerint (Butterworth 1983) minden egyes morfológiailag komplex szóalakot külön tárolunk, azok hangalakjával, jelentésével, szintaktikai funkciójával és egyéb vonásaival. Így tehát mentális szótárunkban külön elem lenne a ház, a háznak, a házról, a házai, a házaim stb. alak. Ez a tárolás gyors hozzáférést biztosít, hiszen a toldalékolt alakokat nem kell lebontani, azok jelentése és egyéb tulajdonságai azonnal rendelkezésre állnak. Ezzel szemben viszont e tárolás igencsak memóriaigényes. A bonyolult morfológiájú nyelvekben, így például a magyarban is, több millió szóalak tárolására lehet szükség. A kísérleti eredmények egészleges tárolást leginkább nagyon gyakori szavak esetén (pl. StembergerMacWhinney 1986; Heffernan-Sato 2017), illetve nem anyanyelvi beszélőknél mutattak ki (pl. Jiang 2004). Mivel ez az elmélet feltételezi, hogy a feldolgozás egyszerűen előhívja a mentális szótárból a feldolgozandó alakot, az alakok ismerete szükséges a feldolgozás sikeréhez. Ez a megközelítés tehát nehezen tudja új alakok feldolgozását, és így a nyelvelsajátítást, a tanulást magyarázni.

Az elemzéses elméletek szerint (Taft 1988) a morfológiailag összetett alakokat a nyelvfeldolgozás során elemeikre bontjuk, pl. háznak: ház+nak stb. Ez erőfeszítést igénylő feldolgozás, hiszen a szótári előhívást megelőzően dekompozíciót igényel. Ugyanakkor kevesebb terhet ró a mentális szótárra, hiszen sokkal kevesebb alak tárolását feltételezi. Ez az elmélet az új, korábban még soha nem hallott alakok lebontását (vagy produkcióját) is jól magyarázza, legalábbis ha azok szabályosak, és éppen ezért a tanulást is jobban képes modellezni.

E két felfogás ötvözeteként sokan kevert modelleket javasolnak (LukatelaCarello-Turvey 1987; Lukatela et al. 1987; Pinker 1997), amelyek szerint bizonyos szóalakokat holisztikusan, másokat elemeikre bontva dolgozunk fel. Hogy pontosan melyikeket hogyan, az múlik többek között az adott nyelv alaktanának általános típusán (agglutináló, flektáló stb.; Slobin-Bever (1982)), az adott szóalak gyakoriságán, szabályos/rendhagyó voltán (Pinker-Prince 1994), azon, hogy szóképzésről vagy toldalékolásról van-e szó stb.

A magyar az erősen agglutináló nyelvek közé tartozik, amelyben ráadásul igen erős az allomorfia, azaz mind a töveknek (pl. majom, majm-), mind a toldalékoknak (pl. - val/-vel hasonulása) gyakran több alakjuk van. Mindehhez még magánhangzóharmónia is társul. Az alaktani feldolgozás tehát a mondatmegértés egyik kulcsfontosságú eleme a magyarban, és mint ilyen kifejezetten alkalmas terep a feldolgozási elméletek vizsgálatára. A magyar morfológia komplexitása az egészleges hozzáférést igen kis hatékonyságú mechanizmussá tenné, így sokkal valószínűbb az analitikus, elemző feldolgozás. A felnőtt magyar beszélőkkel végzett kísérletek, illetve korpuszon végzett számítógépes vizsgálatok valóban ezt is támasztják alá (Kornai 1985; Gergely-Pléh 1994; Pléh-Juhász 1995; Pléh-Lukács 2001; Recski 2014). Klasszikus pszicholingvisztikai kísérletek szódöntési, előfeszítési és azonnali visszaadási paradigmában is bizonyítékot találtak az összetett alakok felbontására a magyarban (Gergely-Pléh 1994; Németh et al. 2006; Magyari 2008). 


\subsection{A magyar alaktan elsajátítása}

Felmerül a kérdés, hogyan sajátítják el a magyar anyanyelvű gyermekek a magyar alaktan komplex rendszerét. A 20. század végén számos kísérletes és korpuszvizsgálatot végeztek tipikusan fejlődő óvodáskorú magyar gyerekekkel a morfológia elsajátításának megértésére (MacWhinney 1975; 2013; MacWhinney-Pléh-Bates 1985; Lukács-Racsmány-Pléh 2001; Pléh-Palotás-Lőrik 2002; Pléh-LukácsRacsmány 2003; Gábor-Lukács 2012), újabban pedig nyelvfejlődési és egyéb zavarokkal küzdő gyermek alaktani tudását is vizsgálták (pl. Lukács-Leonard-Kas 2010). Az alábbiakban csak a toldalékokkal kapcsolatos eredményeket foglalom össze, a magyar alaktan elsajátításának másik sokat tanulmányozott kérdését, az igekötők elsajátítását nem ismeretem, mivel ezt csecsemőknél még nem vizsgálták, így a jelen dolgozat témáját tekintve ez a kérdés kevésbé jelentős.

A vizsgálatok egy része azt dokumentálta, mely toldalékok mikor, milyen sorrendben jelennek meg először a gyermekek beszédében. Az elsajátítási sorrend más nyelvekben megfigyelt elvei a magyarban is érvényesülnek. Így tehát azok a toldalékok, amelynek kognitív tartalmát a gyermekek hamarabb tanulják meg, hamarabb is jelennek meg a beszédben. A múlt idő jelét akkor kezdik a gyermekek használni, ha már (legalább részben) megértették az idő, illetve a múlt fogalmát. A helyhatározók ragjai akkor válnak gyakorivá, amikor a gyermekek érteni kezdik a téri viszonyokat. A toldalékok formája szintén fontos szempont. Az egyszerübb alakú toldalékok hamarabb jelennek meg, mint a bonyolultabbak. Fontos továbbá a jelentéshez való viszony. Az egyértelmű, jól megragadható jelentéssel bíró toldalékokat korábban sajátítják el a gyerekek, mint a szemantikailag kevésbé transzparens alakokat. Nem elhanyagolható a gyakoriság sem: a gyakoribb alakokat hamarabb kezdik használni a gyerekek, mint a ritkábbakat. Ezen elvekkel összhangban, MacWhinney (1976) azt állapította meg, hogy a magyar gyermekek beszédében az első toldalékok már nagyon korán, a kétszavas megnyilatkozásokkal egy időben, tehát másfél-két éves kor körül megjelennek. A főnévragozásban a legkoraibb toldalékok a tárgyrag és a többes szám jele, a hely és az irányragok (-ba, -hoz), a részes eset és a 3 . személyü birtokos jel. Ezek a toldalékok egyrészt nagyon gyakoriak a nyelvi bemenetben, másrészt kognitív-szemantikai szempontból elsődlegesek, mert a cél és az irány kitüntetett kognitív kategóriák a korai kognitív fejlődésben mind a helymeghatározás, mind a cselekvések észlelése és megértése terén (Falck-Ytter-Gredebäck-Hofsten 2006; Csibra 2008; Southgate et al. 2010). Ezeket követik a helyzetet jelölő ragok (p. -on, -nál), illetve az eszköz- és társhatározó (-val). A forrást, eredetet jelülő ragok (-tól, -ból, -ról) a legkésőbbiek. Az igék esetében az egyes szám 3. személyű formák, a felszólító módú alakok és a főnévi igenevek koraiak. Ezt a 2. és 3. személyü formák követik, a tárgyas ragozás és a feltételes mód még későbbiek. Lengyel (1981a; 1981b; 1982) 2-3 éves, valamit Gósy (1984) 3 éves gyerekekkel végzett megfigyelései hasonló mintázatot mutatnak. Ebben a vonatkozásban kifejezetten érdekesek Réger Zita eredményei kétnyelvű magyar-roma kisiskolás gyerekekkel (Réger 1979). Ezek a gyerekek bizonyos toldalékokat, pl. birtokos szerkezetekben, életkoruk ellenére úgy használtak, mint az egynyelvüek óvodás korukban, pl. ez Pistié könyv, azaz a birtokost és nem a birtokot jelölték. Feltételezhető, hogy ez a magyar mellett beszélt másik nyelv hatása. 
E leíró munkák mellett a vizsgálatok arra is kíváncsiak voltak, hogy a beszédben megjelenő toldalékolt alakokat a gyerekek egészlegesen vagy analitikusan hozzáke létre. Ennek egyik fontos ismérve, hogy egy-egy toldalékot több kontextusban, nagy számú szótővel és más toldalékokkal összekapcsolva is használnak-e a gyerekek. Az erre vonatkozó vizsgálatok (Pléh-Vinkler-Kálmán 1997) azt sejtetik, hogy a teljes kombinatorika nem azonnal jelenik meg, pl. a helyragokat a gyerekek sokkal gyakrabban kombinálják 1., mint 2. vagy 3. személyű birtokos személyragokkal (pl. kezemben). Ezzel együtt többszörös toldalékok már a kezdetektöl, 1,5-2,5 éves kortól megjelennek. A morfológia tehát már igen korán legalább részben analitikus a beszédprodukcióban.

Fontos kérdése még ezeknek a vizsgálatoknak, és a fenti eredményekkel összhangban az analitikus reprezentáció irányába mutat, hogy a gyerekek hogyan kezelik a magyarban igen gyakori allomorfiát. Az eredmények szerint az allomorfiát tartalmazó formák elsajátítása úgynevezett U-alakú görbét mutat. A gyermekek a rendhagyó alakokat először jól állítják elő, mert azokat egészlegesen tanulják meg (pl. lovak). Az ezt követő szakaszban hibázni kezdenek, és a hibák túláltalánosítást mutatnak, azaz olyan alakokat hoznak létre, amelyek a felnőtt nyelvben nem léteznek, de szabályosak (pl. lók stb.). Ez már az analitikus reprezentáció és a morfológiai szabályrendszer elsajátítására utal. Az ezt követő végső szakaszban a gyerekek azután megtanulják, mely szavak rendhagyóak, és ismét a felnőtt nyelvben előforduló alakot használják. Ezt a fejlődési útvonalat számos nyelvben leírták (Pinker 1997; Werker-Hall-Fais 2004). A magyarban Pléh, Palotás és Lőrik vizsgálatai (Pléh-Palotás-Lőrik 2002) dokumentálták a jelenséget, és általánosabban az allomorfia elsajátítását. Az eredmények a fejlődés lépéseinek leírása mellett arra is rámutatnak, hogy a különböző allomorf tövek (pl. magánhangzó-kieséses vagy - $v$ betoldásos) nem egyforma nehézséget jelentenek a gyerekeknek, elsajátításuk nem egyszerre, hanem lépésekben zajlik. A szóvégi magánhangzó megnyúlás (almák) például sokkal könnyebb, sokkal hamarabb jelenik meg helyesen, mint a -v betoldás (lovak). Ez utóbbi tövek még kisiskolás gyerekeknél sem mindig helyesek.

Összességében elmondhatjuk tehát, hogy a magyarban a morfológia elsajátítása már igen korán elkezdődik, és bár a fejlődési folyamat évekig eltart, a tanulás a kezdetektől fogva legalább részben szabályok, analitikus reprezentációk mentén halad. Felmerül tehát a kérdés, mikor kezdődik el ez a folyamat. Az is kérdés, hogy a vizsgáltaknál korábbi életkorokban esetleg más mechanizmusok is szerepet játszanak-e. Minderre úgy kaphatunk választ, ha a beszédet még nem produkáló gyermekek, azaz a csecsemők nyelvfeldolgozási, beszédészlelési képességeit vizsgáljuk.

\subsection{A magyar alaktan elsajátításának kezdetei: nyelvészeti megfontolások}

A jelen dolgozat azokat az újabb eredményeket foglalja össze, amelyek a magyar alaktan elsajátításának legkorábbi szakaszait vizsgálják. Ahhoz, hogy a csecsemőkre váró tanulási feladat nehézségét jobban megértsük, elöször röviden összefoglaljuk a megtanulandó nyelvtani jelenségeket, illetve azt vizsgáljuk, ehhez milyen nyelvi bemenetet kapnak a csecsemők. 
Ahogyan korábban már többször említettük, a magyar agglutináló, azaz ragasztó nyelv, amelyben a morfológia fő alapelve, hogy a nyelvtani viszonyokat a szótőhöz kapcsolódó kötött morfémák, azaz toldalékok (szuffixumok) jelzik. A toldalékolást és a toldalékok egymáshoz viszonyított sorrendjét szabályok határozzák meg. Bizonyos agglutináló nyelvek, pl. a baszk, a török, a magyarral ellentétben igen szabályosak, azaz a morfológiai szabályok teljesen produktívak, kevés a kivétel, a rendhagyó alak. A magyarban ezzel ellentétben igen nagy a ragok és tövek allomorfiája, ami nehezíti a tanulást, hiszen az elsajátítás során nem csak az a gyermek feladata, hogy a komplex alakokat elemeire bontsa, hanem az is, hogy a különböző allomorfokat azután azonos szemantikai, szintaktikai stb. reprezentációkhoz kapcsolja (azaz, hogy felismerje, hogy a majom és a majm- tövek jelentése, mondattani szerepe stb. ugyanaz).

Potenciálisan nehezíti a tanulást az is, hogy a toldalékok formája igen változatos. Egyrészt a már említett allomorfia miatt: számos toldaléknak a magánhangzóharmónia és/vagy a hasonulás miatt különböző alakjai vannak (pl. -val/-vel). Másrészt a toldalékok szótagszerkezete is nagyon változatos. Bizonyos toldalékok egyetlen magánhangzóból (pl. birtokos -é) vagy mássalhangzóból (pl. a tárgyrag és a többes szám jele) állnak, míg mások egész szótagot alkotnak (pl. -nak, -hoz stb.). Ennek következtében fonológiai testességük elérő, nem egyformán jól észlelhetőek. Tovább bonyolítja a helyzetet, hogy a rövid, nem egész szótagból álló toldalékok beolvadnak a tő szótagszerkezetébe, azaz a morfémahatárok nem esnek egybe a szótaghatárokkal (pl. morfémahatár: almá|t, de szótagolás: al-mát). Ez azért jelenthet nehézséget, mert a szótagnak a korai beszédészlelésben és nyelvi reprezentációban kitüntetett szerepe van (Bertoncini-Mehler 1981). Sokan feltételezik, hogy a csecsemők, bár érzékenyek az egyes fonémákra is (Eimas et al. 1971), a beszédet alapvetően szótagnyi egységekben reprezentálják. Így azon toldalékok, amelyek nem alkotnak önálló szótagot, nagyobb kihívást jelenthetnek a csecsemők számára.

Ezen nehézségek mellett a komplex morfológiájú nyelvekben általában léteznek olyan morfofonológiai jelenségek is, amelyek feltehetően megkönnyítik az alaktan elsajátítását. Így például az agglutináló nyelvekben gyakori a magánhangzóharmónia. Ez azért jelenthet könnyebbséget a nyelvtanuló számára, mert aharmóniai tartományok kijelölik a morfológiailag komplex szavak határát. Vagyis amikor a hangrend magasról mélyre vagy mélyről magasra változik két szótag között, akkor az szükségképpen szóhatárt és így morfémahatárt jelöl. (Ennek fordítottja nem mindig igaz, nem minden szóhatár jár együtt hangrendi változással, hiszen állhat egymás mellett két ugyanolyan hangrendű szó.) Ezért a magánhangzók hangrendbeli illeszkedésének elsajátítása nem csak önmagáért érdekes, hanem azért is, mert megkönnyítheti a morfológia tanulását is (SuomiMcqueen-Cutler 1997; Vroomen-Tuomainen-de Gelder 1998; Kabak-ManiwaKazanina 2010; Gonzalez-Gomez et al. 2019).

Egy másik jelenség, ami támpontot nyújthat a csecsemőknek a szóhatárok megállapításában és így az alaktan elsajátításában, a szóhangsúly. Számos agglutináló nyelvben, így a magyarban is rögzített a szóhangsúly, az mindig a szónak ugyanarra a szótagjára, a magyarban az elsőre esik. Ennek következtében egy hangsúlyos szótag egyben jelzi a szó első szótagját is, azaz jelet adhat a csecsemőknek a szóhatárokat illetően. Mesterséges nyelvtanulási kísérletekben nem magyar anyanyelvű csecsemőkkel valóban ki is mutatták már, hogy a csecsemők 
sikeresen használják a szóhangsúlyt, amikor folyamatos beszédből kell szóalakokat szegmentálniuk (Vroomen-Tuomainen-de Gelder 1998; Curtin-Mintz-Christiansen 2005; Cunillera et al. 2006).

A toldalékok (és tágabb értelemben a funkciószavak) egyik fontos tulajdonsága, hogy igen gyakoriak, ezért nagyon sokszor fordulnak elő a nyelvi bemenetben, ami megkönnyíti a tanulást. Ahogyan a produkciós adatokban már láttuk, a tárgy eset ragja és a többes szám jele fonológiailag redukált alakjuk ellenére a legkorábban megjelenő toldalékok között vannak, aminek gyakoriságuk az egyik oka.

A toldalékok gyakorisága befolyásolja ezenkívül a nyelvi bemenet teljes statisztikai szerkezetét is, mert hatással van a szótő és a toldalékok közötti átmenetvalószínűségekre is. A nyelvsajátítás irodalmában, még a morfológiailag szegényebb nyelvek, mint pl. az angol esetében is, régóta kérdés, hogyan tudják a csecsemők a folyamatos beszédet elemeire tagolni. A morfológiailag egyszerübb nyelvekben ez gyakran toldalékolatlan szótövekre tagolást jelent, de a bonyolult morfológiájú nyelvekben megkerülhetetlen az alaktani elemzés kérdése is. Ahogyan fent említettük, bizonyos morfofonológiai jelenségek, mint például a hangsúly, a magánhangzóilleszkedés stb. segítséget nyújtanak a csecsemők számára. Ugyanakkor ezek az információk nyelvenként változnak. A szóhangsúly lehet az első, az utolsó előtti vagy az utolsó szótagon, illetve lehetséges, hogy egy nyelvben a hangsúly nem rögzített, hanem lexikai, azaz helye szavanként változik. Magánhangzó-harmónia nem minden nyelvben van, ez azokban, amelyekben igen, az illeszkedés eltérő fonológiai jegyek mentén történhet. Így ezen morfofonológiai információk leginkább a már idősebb csecsemőknek szolgálhatnak támpontként, akik az anyanyelvük hangrendszerét legalább részben már ismerik. De vajon mi az az információ, amely egyetemesen minden nyelvben használható, és így a kezdeti szegmentációt irányíthatja? Egyes javaslatok szerint (Brent-Cartwright 1996; Saffran-Aslin-Newport 1996) a beszéd statisztikai szerkezete, azon belül is a szótagok vagy fonémák együttes előfordulási vagy átmenetvalószínűsége ilyen információ lenne. A javaslat azon a megfigyelésen alapszik, hogy az egyazon szó belsejében előforduló szótagok vagy fonémák nagyobb valószínűséggel jósolják meg egymást, mint a szóhatárok két oldalán állók. A cu- szótag például nagyobb valószínűséggel jósolja be a -kor szótagot, mint a -kor szótag a következőt. Az A és B elemek közötti előre mutató (1a) és visszafelé mutató (1b) átmenetvalószínűségek definíciója

$$
\begin{array}{ll}
\text { a. } & P(A \rightarrow B)=F(A B) / F(A) \\
\text { b. } & P(A \leftarrow B)=F(A B) / F(B)
\end{array}
$$

ahol $\mathrm{P}$ az átmenetvalószínűség, $\mathrm{F}(\mathrm{X})$ pedig $\mathrm{X}$ elem gyakorisága. $\mathrm{A}$ csecsemők érzékenyek a szótagok közötti átmenetvalószínűségekre (Saffran-Aslin-Newport 1996), és szóhatárt feltételeznek ott, ahol az átmenetvalószínüség alacsony.

Mivel az átmenetvalószínűség nemcsak a két szótag együttes előfordulásának gyakoriságától függ, hanem azt az egyik szótag gyakorisága is kondicionálja, a nagyon gyakori szótagok, amilyenek az át nem szótagolódó toldalékok is, befolyásolják tehát a nyelvi input statisztikai szerkezetét. Minél gyakoribb a kondicionáló szótag, az átmenetvalószínüség értéke annál kisebb. A gyakori toldalékok körül tehát az átmenetvalószínűség lecsökken, a szegmentálás könnyebbé válik. 
Egy korpuszvizsgálatban arra voltunk kíváncsiak (Gervain-Guevara Erra 2012), vajon a nyelv morfoszintaktikai típusa befolyásolja-e az átmenetvalószínűségek eloszlását és így a bemenet szegmentálhatóságát. Gyerekekhez intézett olasz és magyar beszélt nyelvi korpuszon vizsgáltuk meg, hogy e két, tipológiailag igen különböző nyelvben (olasz: flektáló, Ige-Tárgy szórendű; magyar: agglutináló, kevert Ige-Tárgy/Tárgy-Ige szórendű) mások-e az átmenetvalószínúségek eloszlásai. Eredményeink szerint az átmenetvalószínűségekkel mindkét nyelvben a véletlennél jobb szegmentálást lehet elérni, de érdekes módon az átmenetvalószínüségek érzékenyek a morfológiára. Az olaszban az előre mutató átmenetvalószínűség, míg a magyarban a visszafelé mutató ért el jobb eredményeket. A rosszabbul teljesítő valószínűség mindkét nyelv esetében csak alig valamivel volt jobb a véletlennél, míg a jobban szegmentáló valószínűség kifejezetten eredményes volt. A két nyelv között megfigyelt különbség jól visszavezethető azok morfoszintaktikai jellemzőire. Az olasz viszonylag gyenge morfológiájú, flektáló nyelv, aránylag kevés szuffixummal, míg szórendjéből adódóan a szabad funkciószavak (pl. prepozíciók) a szintagmák elején állnak. A gyakori szótagok tehát sokszor vannak kezdeti pozícióban, ami azt eredményezi, hogy az előre menő átmenetvalószínűségek kifejezetten alacsonyak lesznek ilyen esetekben, sikeresen jelezvén a szóhatárokat. A magyarban ezzel szemben sok szuffixumot találunk, azaz a gyakori elemek inkább hátsó pozícióban vannak, így a visszafelé menő átmenetvalószínűségek lesznek alacsonyak azokon a helyeken, ahol a gyakori funkciószók előfordulnak. Bár a visszafelé mutató átmenetvalószínűségek nem tűnnek kognitív szempontból igen hatékony vagy könnyen használható stratégiának, hiszen a beszéd időben „elörefelé” halad, kísérleti eredmények azt mutatják, hogy a felnőttek és a csecsemők is képesek a visszafelé mutató átmenetvalószínűségeket kiszámolni és egyszerű nyelvi ingerek szegmentálására használni (Perruchet-Desaulty 2008; Pelucchi-Hay-Saffran 2009).

A magyarban külön azt is megvizsgáltuk, hogy az átmenetvalószínűségek vajon a morfológiailag komplex szavak határát vagy a morfémák (azaz külön a szótövek és külön a toldalékok) határát jelzik-e inkább. Azt találtuk, hogy az átmenetvalószínűségek mindkét esetben ugyanolyan jól teljesítenek. Ennek azonban nem az az oka, hogy e statisztikai stratégia különösen jól szegmentálja a morfémahatárokat. Inkább arról van szó, hogy a gyermekekhez intézett beszédben a morfológia viszonylag egyszerű, kevés a halmozott toldalék, és a leggyakoribb toldalékok vannak túlsúlyban, a ritkábbak szinte alig fordulnak elő. Márpedig a leggyakoribb toldalékok (tárgyrag, többes szám, birtokos jel stb.) tipikusan fonológiailag testetlenek, így nem alkotnak önálló szótagot. Éppen ezért a szótagok között számított átmenetvalószínüségek számára ezek a morfémahatárok láthatatlanok. ( $A$ fonémák közötti átmenetvalószínüségek pedig általában nagyon alacsonyan teljesítenek, sokkal alacsonyabban, mint a szótagok közöttiek, ezért nem tűnnek plauzibilis szegmentálási stratégiának.) Mivel a leggyakoribb toldalékok statisztikai szegmentálással nem kaphatóak meg a magyarban, valószínü, hogy elsajátításukban más szempontok játszanak szerepet, pl. az egyszerủ abszolút gyakoriság.

Összefoglalva tehát a komplex magyar alaktan komoly kihívás elé állítja a nyelvtanulót, ugyanakkor léteznek olyan támpontok, információk a nyelvi bemenetben, amelyeket a csecsemők segítségül hívhatnak. 


\section{A magánhangzó-harmónia megjelenése}

Az egyik ilyen információ a magánhangzó-harmónia. Ahogyan korábban említettük, a hangrend változása szóhatárt jelez, ami segíti a szegmentálást. Kérdés tehát, mikortól érzékenyek a csecsemők arra, hogy anyanyelvükben magánhangzó-harmónia érvényesül. Igen kevés kísérletes vizsgálat létezik a magánhangzó-harmónia elsajátításáról. A meglevő eredmények szerint a 6 hónapos török csecsemők már hosszabb ideig hallgatnak harmonikus, mint nem harmonikus szavakat, míg a német csecsemők esetén nincs különbség a két szólista hallgatási idejei között. Mivel a törökben van magánhangzó-harmónia, míg a németben nincs, ez azt sejteti, hogy a szótöveken belül előforduló harmóniára a 6 hónapos török csecsemők anyanyelvi tapasztalatuknál fogva már érzékenyek (van Kampen et al. 2008). Ugyanebben az életkorban a szótő és a toldalék közötti illeszkedést is már elvárják, mivel hosszabb ideig hallgatják az illeszkedő toldalékolt alakokat, mint a hangrendi illeszkedést megszegőeket, akár a magánhangzó magassága, akár ajakkerekítés volt az illeszkedés alapja (Altan-Kaya-Hohenberger 2016; Hohenberger-Kaya-Altan 2017).

A török azonban a magyarnál jobban betartja a magánhangzó-harmónia elvét. Gyerekekhez intézett beszédkorpuszokban a magyar szavaknak csak $70 \%$ mutat harmóniát (Gonzalez-Gomez et al. 2019), akár szótövekről, akár több morfémából álló szavakról van szó, míg a törökben a harmonizáló szavak aránya inkább $90 \%$ körül van (Ketrez 2014). Éppen ezért felmerül a kérdés, hogy a magyar csecsemők, akik kevésbé szabályos nyelvi bemenetet kapnak, vajon ugyanabban az időben sajátítják-e el a harmónia elvét, mint a török gyerekek.

Ennek vizsgálatára 10 és 13 hónapos magyar csecsemőket tesztelünk, valamint kontrollként 13 hónapos francia babákat, akiknek az anyanyelve nem mutat harmóniát. A kísérletben mindhárom csoport ugyanazt az ingeranyagot hallgatta: olyan magánhangzó-mássalhangzó-magánhangzó szerkezetü álszavakat, amelyeknek egy része harmonizált (pl. üki, oba stb.), másik részük viszont megsértette az illeszkedés elvét (pl. igo, eda stb.). A kísérletben azt mértük, a csecsemők mennyi ideig hallgatják a harmonizáló és a nem harmonizáló szólistákat (illetve, hogy milyen sokáig nézik a hozzájuk kapcsolódó vizuális ingert, ami egy villogó lámpa volt).

A három csoport közül csak a 13 hónapos magyar csecsemők mutattak különbséget a harmonizáló és a nem harmonizáló szólisták között: hosszabb ideig nézték a nem harmonizáló, tehát a magyarhoz képest új, meglepő szavakat. ${ }^{1}$ Ez azt jelenti, hogy meg tudták különböztetni a két szótípust. A másik két csoport, azaz a fiatalabb magyar babák, és az azonos korú francia babák egyforma hosszan nézték a két szótípust, nem mutattak érzékenységet a harmóniára.

\footnotetext{
${ }^{1}$ Első pillantásra meglepő lehet, hogy míg a török csecsemőkkel végzett kísérletekben a babák az anyanyelvükhöz hasonló, harmonikus szavakat hallgatták hosszabb ideig, addig e kísérletben a magyar csecsemők a nem harmonizáló alakokra figyeltek tovább. A nézési idős csecsemővizsgálatokban igen gyakori a preferencia irányának változása. Az ingerek bonyolultsága, érdekessége, a gyermekek kora és a feladat általános nehézsége függvényében bizonyos kísérletekben a csecsemők az ismert (anyanyelvhez hasonló, korábban hallott stb.), más kísérletekben az újszerü, ismeretlen, meglepő ingereket nézik/hallgatják tovább (HunterAmes-Koopman 1983). Bár az eredmények értelmezése szempontjából nem lényegtelen a preferencia iránya, mindkét irányú preferenciát a diszkrimináció jeleként szoktuk értelmezni.
} 


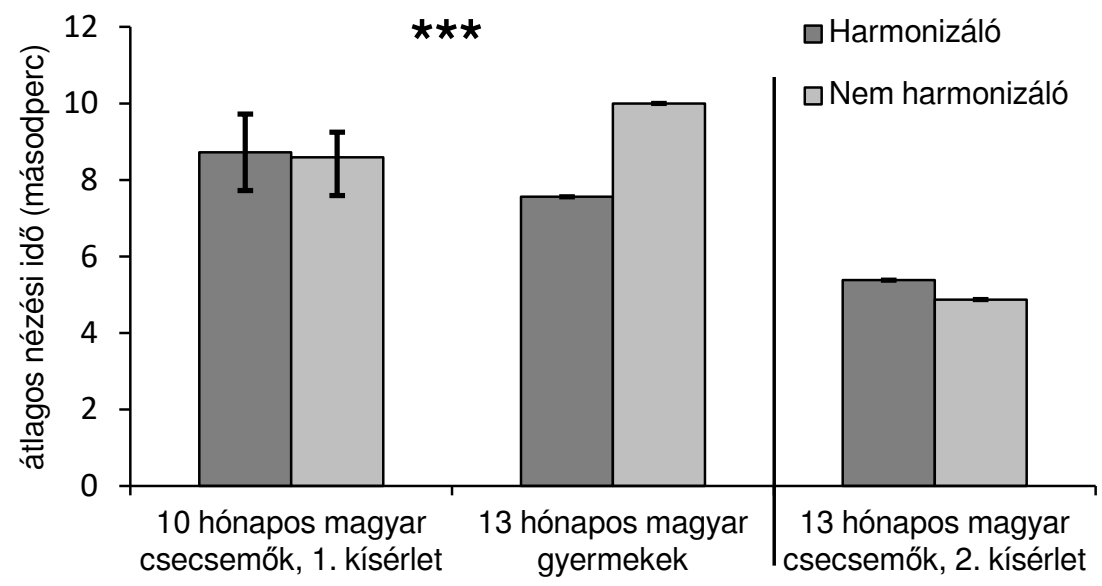

1. ábra

A magánhangzó-harmóniára csak a 13 hónapos magyar csecsemők érzékenyek (Gonzalez-Gomez et al. 2019). Az x tengely a három csoportot mutatja (10 és 13 hónapos magyar csecsemők, 13 hónapos francia csecsemők). Az y tengely a nézési időt ábrázolja másodpercben kifejezve. A sötétszürke oszlopok a harmonizáló, a világosszürke oszlopok a nem harmonizáló szólisták nézési idejeit mutatják.

Ez azt sejteti tehát, hogy a magyar gyerekek 10 és 13 hónapos kor között tanulják meg, hogy anyanyelvükben érvényesül a magánhangzó-harmónia elve. Ezt nem lehet egyszerűen azzal magyarázni, hogy a nem harmonizáló tövek önmagukban érdekesebbek, hiszen a 13 hónapos francia csecsemők és a fiatalabb magyarak babák nem mutattak irántuk preferenciát.

Mivel a szótanulás a második életévben indul meg igazán, a magánhangzóharmónia elve elég korán jelenik meg ahhoz, hogy valóban segítséget tudjon nyújtani a szavak elsajátításában. Általánosabban véve is hozzájárulhat a morfológia elsajátításához, hiszen számos toldaléknak van két különböző hangrendű (plusz akár ajakkerekítés szempontjából illeszkedő alakja). A magánhangzó-harmónia ismerete nélkül nehéz lenne ezek allomorfokat a lexikonban összekötni, illetve azután a produkcióban a toldalékolást megfelelően használni.

\section{A ragok leválasztása}

Az egyik legfontosabb kérdés a magyar alaktan elsajátításával kapcsolatban az, mikortól képesek a csecsemők a toldalékolt szóalakokban a toldalékot a szótőről leválasztani, azaz mikor indul meg a morfológiai dekompozíció.

E kérdés viszonylag kevés figyelmet kapott a csecsemők beszédészlelésének kutatása során. A létező eredmények azt mutatják, hogy angol és francia anyanyelvü csecsemők 1 éves koruk körül kezdik a toldalékolt alakokat elemeikre bontani. Egy kanadai francia babákkal végzett tanulmányban (Marquis-Shi 2012) a 
csecsemőket először egy álszóval familiarizálták, majd a tesztfázisban a babák olyan mondatokat hallottak, amelyben vagy a familiarizált álszó, vagy egy korábban nem hallott álszó fordult elő a leggyakoribb igei szuffixummal. Ha babák a toldalékot képesek leválasztani, akkor a familiarizált álszó ismerősen fog nekik hangozni, míg a korábban nem hallott álszó nem. Ha viszont nem képesek morfológiai elemzésre, akkor mindkét szó újként hat. A kutatók azt találták, hogy a 11 hónapos kanadai francia babák hosszabban néztek a familiarizált álszót tartalmazó mondatok esetében, ami azt jelzi, hogy a szóalakot elemeire bontották. Ha a gyakori igei szuffixum helyett egy álszuffixumot használtak a mondatokban, akkor a babák válaszai nem különböztek az ismert és a korábban nem hallott álszót tartalmazó mondatok esetén. E kísérletet továbbgondolva Mintz (2013) egy ökológiai szempontból érvényesebb paradigmát javasolt. Ő a csecsemőket a mondatokhoz familiarizálta, amelyekben ugyanúgy, mint a korábbi kísérletben, egy-egy toldalékolt álszó jelent meg. A tesztfázisban azután a csecsemőket az álszó szótővel és egy korábban nem hallott álszóval tesztelte. Ez a helyzet jobban hasonlít arra, ami a valóságban a nyelvtanulás során történik, azaz hogy a csecsemőknek toldalékolt alakokból kell a szótövet (és a toldalékokat) elvonatkoztatni. A kísérlet azt mutatta, hogy a 15 hónapos amerikai babák hosszabb ideig hallgatták a már ismert álszótövet a korábban nem hallottnál, ami arra enged következtetni, hogy a mondatok hallgatása közben elemeire bontották a komplex szóalakot.

Két kísérletben (Ladányi-Kovács-Gervain elbírálás alatt), amelyek Mintz (2013) paradigmáját követik, arra kerestünk választ, vajon a magyar csecsemők mikor mutatják először jelét a morfológiai dekompozíciónak. A magyar bonyolult morfológiája egyfelől arra kényszerítheti a babákat, hogy már korán elkezdjék a morfológiai elemzést, mert a nagy számú alakot túl nehéz lenne egészlegesen tárolni. De az is elképzelhető, hogy az alakok nagy száma és az erős allomorfia, azaz a feladat nehézsége miatt a morfológiai elemzés csak később kezdődik el, mint az angolban vagy a franciában.

Vizsgálatunkban 15 hónapos magyar csecsemőknek olyan mondatokat játszottunk le, amelyekben egy álszóhoz egy létező, a beszédben igen gyakori toldalék (-ban) kapcsolódott (pl. A púrban nézegeti a virágokat). A babák egy másik csoportja olyan mondatokat hallott, amelyben áltoldalék (-dag) szerepelt az álszótővel (pl. A púrdag nézegeti a virágokat). Arra ügyeltünk, hogy a mondatok nyelvtanilag helyesek legyenek, akár morfológiailag összetettnek (púrban/púrdag házban), akár egyszerűnek (púrban/púrdag macska) értelmezzük az álszót. A tesztszakaszban azután a babák vagy a familiarizált álszótőt (púr) vagy egy újat hallottak (gál). Ha a csecsemők már tudják, hogy a -ban létező rag a magyarban, és le tudják azt a szótőről választani, akkor a tesztfázisban a púr szótő ismerős lesz nekik. Azok a csecsemők viszont, akik az áltoldalékot hallották, nem támaszkodhatnak anyanyelvi tudásukra, hogy dekompozíciót hajtsanak végre, így számukra a két álszó a tesztfázisban nem lesz különböző.

Azt kaptuk eredményül, hogy azok a csecsemők, akik a valódi ragot hallották a familiarizáció során, a tesztfázisban hosszabban néztek az ismeretlen álszó esetén, mint a familiarizált álszónál, legalábbis a tesztfázis első felében. Ezzel szemben azok a babák, akik a nem létező szuffixumot hallották, nem mutattak semmilyen különbséget a tesztben. Ez arra enged következtetni, hogy a 15 hónapos magyar 
csecsemők már reprezentálják a -ban ragot, és azt egy korábban soha nem hallott szótőről is képesek leválasztani.

A kísérletet magas hangrendű álszavakkal és toldalékokkal is megismételtük. Az eredmény ebben az esetben is ugyanaz volt: a csecsemők sikeresen leválasztották a -ben ragot a magas hangrendű álszóról.

Eredményeink szerint tehát 15 hónapos korukra a magyar csecsemők már ismerik a leggyakoribb főnévi toldalékokat, és azokat ismeretlen szavakról is sikeresen leválasztják, akár magas, akár mély hangrendűek azok.

\section{4. Összegzés}

A magyar nyelv alaktana bonyolult, komoly kihívást jelent a nyelvtanulók számára. A kisgyermekek azonban már igen korán használni kezdenek bizonyos toldalékokat beszédükben. A jelen tanulmány célja az volt, hogy rámutasson e tanulási folyamat nyelvészeti és pszichológiai szempontból fontos mozzanataira, és összefoglalja azon újabb kísérletes vizsgálatokat, amelyek az alaktan elsajátításának legelső lépéseit tárják fel. A morfológia elsajátításának kezdetei még számos rejtélyt tartogatnak, de a bemutatott kísérletek arra engednek következtetni, hogy a magyar csecsemők az első életévük végén, a második elején már jól ismerik az agglutináló morfológia alapelveit, hatékonyan bontják a szóalakokat morfémákra.

Ez a nyelvtanulás egésze szempontjából azt jelenti, hogy a második életévben bekövetkező szótári „robbanást”, azaz a szókincs rohamos növekedését, a gyors szótanulást a magyarban kompetens morfológiai feldolgozás segíti. Az elméleti viták tükrében ez arra enged következtetni, hogy a szókincs reprezentációja már nagyon korán analitikus. Nyitott kérdés marad, hogy ezt megelőzően, a szótanulás legeslegelső szakaszában, 6-12 hónapos korban, amikor nagyrészt még a szóformák szegmentálása zajlik, a reprezentált formákhoz a csecsemők még nem feltétlenül kapcsolnak referenciális jelentést, akkor egészlegesen tárolt alakok is jelen vannak-e.

\section{Hivatkozások}

Altan, Aslı - Utku Kaya - Annette Hohenberger 2016. Sensitivity of Turkish infants to vowel harmony in stem-suffix sequences: preference shift from familiarity to novelty. In Jennifer Scott - Deb Waughtal (szerk.) BUCLD 40 Online Proceedings Supplements. https://tinyurl.com/JENY-2019-2-Ger1.

Bertoncini, Josiane - Jacques Mehler 1981. Syllables as units in infant speech perception. Infant Behavior and Development 4:247-260. doi:10.1016/S0163-6383(81)80027-6.

Brent, Michael R. - Timothy A. Cartwright 1996. Distributional regularity and phonotactic constraints are useful for segmentation. Cognition 61/1-2:93-125. doi:10.1016/S0010-0277(96)00719-6.

Butterworth, Brian 1983. Lexical representation. In Brian Butterworth (szerk.) Language Production. Vol. 2. London: Academic Press. 257-294. 
Cunillera, Toni - Juan M. Toro - Nuria Sebastián-Gallés - Antoni Rodríguez-Fornells 2006. The effects of stress and statistical cues on continuous speech segmentation: An event-related brain potential study. Brain Research 1123/1:168-178. doi:10.1016/j.brainres.2006.09.046.

Curtin, Suzanne - Toben H. Mintz - Morten H. Christiansen 2005. Stress changes the representational landscape: Evidence from word segmentation. Cognition 96/3:233-262. doi:10.1016/j.cognition.2004.08.005.

Csibra, Gergely 2008. Goal attribution to inanimate agents by 6.5 -month-old infants. Cognition 107/2:705-717. doi:10.1016/j.cognition.2007.08.001.

Eimas, Peter D. - Einar R. Siqueland - Peter Jusczyk - James Vigorito 1971. Speech perception in infants. Science 171/3968:303-306. doi:10.1126/science.171.3968.303.

Falck-Ytter, Terje - Gustaf Gredebäck - Claes von Hofsten 2006. Infants predict other people's action goals. Nature Neuroscience 9/7:878-879. doi:10.1038/nn1729.

Gábor, Bálint - Ágnes Lukács 2012. Early morphological productivity in Hungarian: Evidence from sentence repetition and elicited production. Journal of Child Language 39/2:411-442. doi:10.1017/S0305000911000110.

Gergely, György - Csaba Pléh 1994. Lexical processing in an agglutinative language and the organization of the lexicon. Folia Linguistica 28/1-2:175-204. doi:10.1515/flin.1994.28.1-2.175.

Gervain, Judit - Ramón Guevara Erra 2012. The statistical signature of morphosyntax: A study of Hungarian and Italian infant-directed speech. Cognition 125/2:263287. doi:10.1016/j.cognition.2012.06.010.

Giraudo, Hélène - Serena Dal Maso 2016. The salience of complex words and their parts: Which comes first? Frontiers in Psychology 7/1778. doi:10.3389/fpsyg.2016.01778.

Goldowsky, Boris N. - Elissa L. Newport 1993. Modeling the effects of processing limitations on the acquisition of morphology: The less is more hypothesis. In Eve V. Clark (szerk.) The Proceedings of the Twenty-fourth Annual Child Language Research Forum. Stanford: Center for the Study of Language (CSLI). 124-138.

Gonzalez-Gomez, Nayeli - Silvana Schmandt - Judit Fazekas - Thierry Nazzi Judit Gervain 2019. Infants' sensitivity to nonadjacent vowel dependencies: The case of vowel harmony in Hungarian. Journal of Experimental Child Psychology 178:170-183. doi:10.1016/j.jecp.2018.08.014.

Gósy Mária 1984. Hangtani és szótani vizsgálatok hároméves gyermekek nyelvében. Budapest: Akadémiai Kiadó.

Heffernan, Kevin - Yo Sato 2017. Relative frequency and the holistic processing of morphology. Asia-Pacific Language Variation 3/1:67-94. doi:10.1075/aplv.3.1.

Hohenberger, Annette - Utku Kaya - Aslı Altan 2017. Discrimination of vowelharmonic vs vowel-disharmonic words by monolingual Turkish infants in the first year of life. In Maria LaMendola - Jennifer Scott (szerk.) Proceedings of the 41st annual Boston University conference on language development. Somerville: Cascadilla Press. 309-322. 
Hunter, Michael A. - Elinor W. Ames - Raymond Koopman 1983. Effects of stimulus complexity and familiarization time on infant preferences for novel and familiar stimuli. Developmental Psychology 19/3:338-352.

doi:10.1037/0012-1649.19.3.338.

Jiang, Nan 2004. Morphological insensitivity in second language processing. Applied Psycholinguistics 25/4:603-634. doi:10.1017/S0142716404001298.

Kabak, Barış - Kazumi Maniwa - Nina Kazanina 2010. Listeners use vowel harmony and word-final stress to spot nonsense words: A study of Turkish and French. Laboratory Phonology 1/1:207-224.

Kampen, Anja van - Güliz Parmaksiz - Ruben van de Vijver - Barbara Höhle 2008. Metrical and statistical cues for word segmentation: The use of vowel harmony and word stress as cues to word boundaries by 6 -and 9-month-old Turkish learners. In Anna Gavarró - M. João Freitas (szerk.) Language Acquisition and Development: Proceedings of GALA 2007. Newcastle: Cambridge Scholars Publishing. 313-324.

Kornai, András 1985. The internal structure of Noun Phrases. In István Kenesei (szerk.) Approaches to Hungarian 1. Szeged: JATE. 79-93.

Ladányi, Enikő - Ágnes Melinda Kovács - Judit Gervain elbírálás alatt. How 15month-old infants process morphologically complex forms in an agglutinative language?

Leminen, Alina - Minna Lehtonen - Mirjana Bozic - Harald Clahsen 2016. Editorial: Morphologically complex words in the mind/brain. Frontiers in Human Neuroscience 10:47. doi:10.3389/fnhum.2016.00047.

Lengyel Zsolt 1981a. A gyermeknyelv. Budapest: Gondolat.

Lengyel Zsolt 1981b. Tanulmányok a nyelvelsajátítás köréböl. (Nyelvtudományi Értekezések 107) Budapest: Akadémiai Kiadó.

Lengyel Zsolt 1982. Gyermeknyelvi kutatások Magyarországon. Óvodai Nevelés 9.

Lukács, Ágnes - Laurence B. Leonard - Bence Kas 2010. Use of noun morphology by children with language impairment: The case of Hungarian. International Journal of Language \& Communication Disorders 45/2:145-161. doi:10.3109/13682820902781060.

Lukács, Ágnes - Mihály Racsmány - Csaba Pléh 2001. Vocabulary and morphological patterns in Hungarian children with Williams syndrome: A preliminary report. Acta Linguistica Hungarica 48/1:243-269.

Lukatela, Georgije - Claudia Carello - Michael T. Turvey 1987. Lexical representation of regular and irregular inflected nouns. Language and Cognitive Processes 2/1:1-17. doi:10.1080/01690968708406349.

Lukatela, Georgije - A. Kostić - Dejan Todorović - Claudia Carello - Michael T. Turvey 1987. Type and number of violations and the grammatical congruency effect in lexical decision. Psychological Research 49/1:37-43. doi:10.1007/BF00309201.

MacWhinney, Brian 1975. Rules, rote, and analogy in morphological formations by Hungarian children. Journal of Child Language 2/1:65-77. doi:10.1017/S0305000900000891.

Macwhinney, Brian 1976. Hungarian research on the acquisition of morphology and syntax. Journal of Child Language 3/3:397-410. doi:10.1017/S0305000900007261. 
MacWhinney, Brian 2013. Hungarian language acquisition as an exemplification of a general model of grammatical development. In Dan Isaac Slobin (szerk.) The Crosslinguistic Study of Language Acquisition. Hillsdale: Psychology Press. 121-302.

MacWhinney, Brian - Csaba Pléh - Elizabeth Bates 1985. The development of sentence interpretation in Hungarian. Cognitive Psychology 17/2:178-209. doi:10.1016/0010-0285(85)90007-6.

Magyari Lilla 2008. A mentális lexikon modelljei a magyar nyelvben. In Gervain Judit - Pléh Csaba (szerk.) A láthatatlan nyelv. Budapest: Gondolat Kiadó. 98-119.

Marquis, Alexandra - Rushen Shi 2012. Initial morphological learning in preverbal infants. Cognition 122/1:61-66. doi:10.1016/j.cognition.2011.07.004.

Milin, Petar - Eva Smolka - Laurie Beth Feldman 2017. Models of lexical access and morphological processing. In Eva M. Fernández - Helen Smith Cairns (szerk.) The Handbook of Psycholinguistics. John Wiley \& Sons. 240-268. doi:10.1002/9781118829516.ch11.

Mintz, Toben H. 2013. The segmentation of sub-lexical morphemes in Englishlearning 15-month-olds. Frontiers in Psychology 4/24. doi:10.3389/fpsyg.2013.00024.

Németh Dezső - Ivády Rozália Eszter - Miháltz Márton - Krajcsi Attila - Pléh Csaba 2006. A verbális munkamemória és a morfológiai komplexitás. Magyar Pszichológiai Szemle 61/2:265-298. doi:10.1556/MPSzle.61.2006.2.4.

Pelucchi, Bruna - Jessica F. Hay - Jenny R. Saffran 2009. Learning in reverse: Eight-month-old infants track backward transitional probabilities. Cognition 113/2:244-247. doi:10.1016/j.cognition.2009.07.011.

Perruchet, Pierre - Stéphane Desaulty 2008. A role for backward transitional probabilities in word segmentation? Memory \& Cognition 36/7:1299-1305. doi:10.3758/MC.36.7.1299.

Pinker, Steven 1997. Words and rules in the human brain. Nature 387/6633:547548. doi:10.1038/42347.

Pinker, Steven - Alan Prince 1994. Regular and irregular morphology and the psychological status of rules of grammar. In Susan D. Lima - Roberta Corrigan - Gregory K. Iverson (szerk.) The Reality of Linguistic Rules. (Studies in Language Companion 26) Amsterdam: John Benjamins Publishing Company. 321-352. doi:10.1075/slcs.26.21pin.

Pléh Csaba 1980. A pszicholingvisztika horizontja. Budapest: Akadémiai Kiadó.

Pléh Csaba - Juhász Levente 1995. Processing of multimorphemic words in Hungarian. Acta Linguistica Hungarica 43/1-2:211-230.

Pléh Csaba - Lukács Ágnes 2001. A magyar morfológia pszicholingvisztikája. Budapest: Osiris Kiadó.

Pléh, Csaba - Ágnes Lukács - Mihály Racsmány 2003. Morphological patterns in Hungarian children with Williams syndrome and the rule debates. Brain and Language 86/3:377-383. doi:10.1016/S0093-934X(02)00537-0.

Pléh Csaba - Palotás Gábor - Lőrik József 2002. Nyelvfejlődési szúrővizsgálat $(P P L)$. Budapest: Akadémiai Kiadó.

Pléh Csaba - Vinkler Zsuzsanna - Kálmán László 1997. Early morphology of spatial expressions in Hungarian children: A CHILDES study. Acta Linguistica Hungarica 44/1-2:249-260. 
Recski, Gábor 2014. Hungarian noun phrase extraction using rule-based and hybrid methods. Acta Cybernetica 21/3:461-479. doi:10.14232/actacyb.21.3.2014.11.

Réger, Zita 1979. Bilingual Gypsy children in Hungary: Explorations in 'natural' second-language acquisition at an early age. International Journal of the Sociology of Language 1979/19:59-82. doi:10.1515/ijsl.1979.19.59.

Saffran, Jenny R. - Richard N. Aslin - Elissa L. Newport 1996. Statistical learning by 8-month-old infants. Science 274/5294:1926-1928. doi:10.1126/science.274.5294.1926.

Sandra, Dominiek - Marcus Taft (szerk.) 1994. Morphological Structure, Lexical Representation and Lexical Access. Taylor \& Francis.

Slobin, Dan I. - Thomas G. Bever 1982. Children use canonical sentence schemas: A crosslinguistic study of word order and inflections. Cognition 12/3:229-265. doi:10.1016/0010-0277(82)90033-6.

Southgate, Victoria - Mark H. Johnson - Imen El Karoui - Gergely Csibra 2010. Motor system activation reveals infants' on-line prediction of others' goals. Psychological Science 21/3:355-359. doi:10.1177/0956797610362058.

Stemberger, Joseph Paul - Brian MacWhinney 1986. Frequency and the lexical storage of regularly inflected forms. Memory \& Cognition 14/1:17-26. doi:10.3758/BF03209225.

Suomi, Kari - James M. Mcqueen - Anne Cutler 1997. Vowel harmony and speech segmentation in Finnish. Journal of Memory and Language 36/3:422-444. doi:10.1006/jmla.1996.2495.

Taft, Marcus 1988. A morphological-decomposition model of lexical representation. Linguistics 26/4:657-668. doi:10.1515/ling.1988.26.4.657.

Vroomen, Jean - Jyrki Tuomainen - Beatrice de Gelder 1998. The roles of word stress and vowel harmony in speech segmentation. Journal of Memory and Language 38/2:133-149. doi:10.1006/jmla.1997.2548.

Werker, Janet F. - D. Geoffrey Hall - Laurel Fais 2004. Reconstruing U-shaped functions. Journal of Cognition and Development 5/1:147-151. doi:10.1207/s15327647jcd0501_15.

\section{A szerzőről}

Gervain Judit nyelvész és kognitív idegtudós. A párizsi Integrative Neuroscience and Cognition Center (CNRS és Université Paris Descartes) kutatója. A csecsemőkori beszédészleléssel, a korai nyelvelsajátítással és azok idegi alapjainak kutatásával foglalkozik.

Elérhetősége: judit.gervain@parisdescartes.fr 